\title{
Correlation and Path Analysis of Morpho-physiological Parameters Contributing to Leaf Yield in Mulberry (Morus alba L.,) under Salt Affected Soils in India
}

\author{
K. Sathyanarayana* and P. A. Sangannavar \\ Central Silk Board, Govt. of India, BTM Layout, Bengaluru-560 068, Karnataka, India \\ *Corresponding author
}

Keywords

Correlation, Path analysis,

Morphological traits, Leaf yield, Morus alba, Alkali Soil

Article Info

Accepted:

15 April 2020

Available Online:

10 May 2020
A B S T R A C T

Current experiment is conducted to study correlation and path analysis among morphological parameter and their contribution towards mulberry leaf yield taken up at an alkali hot spot in Karnataka in untreated alkali soil, alkali soils reclaimed with inorganic and organic amendment by growing five alkali tolerant mulberry genotypes alongwith two improved genotypes and one ruling local check at Central Sericulture Research and Training Institute, Central Silk Board, Mysuru. Genotypes were significantly varied $(\mathrm{p}<0.01-0.05)$ in morpho-physicological parameters and leaf yield. In addition, morpho-physiological parameters such as leaf area, specific leaf weight and leaf moisture percentage exhibited positive and significant correlation at both phenotypic as well as genotypic level with leaf yield under untreated alkali soil, alkali soils reclaimed with inorganic and organic amendment. From the study it is indicated that the overall performance of the mulberry genotypes with respect to all the parameters improved significantly, when organic amendment through pressmud was considered.

\section{Introduction}

Sericulture is an agro based industry comprising a unique combination of four major components such as cultivation of host plants for quality leaf production, rearing silkworm for cocoon production, reeling of cocoon to take out silk yarn from cocoons, and fabric production. Each of the above components has numerous sub-components and success of them depends on the availability of technical know-hows and technologies. For example in host plant cultivation needs thorough knowledge on the environment, soil structure and fertility, availability of suitable plant varieties, farm machineries and technologies, chemical and instruments for pest and disease management, harvesting and storage of leaf for silkworm rearing. Although India produces, all the four 
major commercial silk fibers (35468 MT), more than $70 \%$ of the silk comes from mulberry silkworm (25344 MT) (Anonymous 2019). Mulberry silkworm solely feed on Morus sps, with a total of 2,35,001 ha area under mulberry plantation in India (Anonymous 2019). As the mulberry leaf production accounts for more than $60 \%$ of the cocoon production cost (Rangaswamy et al., 1976, Venkatanarasaiah, 1992), mulberry cultivation has a significant role to play for the sustainability of sericulture in any country. The nutritional status of mulberry leaves influences the silkworm nutrition as the growth of the silkworm entirely depends upon the levels of proteins, carbohydrates, minerals etc., in the leaves (Anonymous, 1975).

The choice of increasing income from sericulture is between either vertical growth or horizontal growth. Expansion of area under mulberry (horizontal growth) is the quicker and easier option for growth of sericulture provided suitable additional land is available. The only alternative therefore is to explore the new areas, which are apparently not suited for growing agricultural crops. In India 24.36 million hectare geographical area is affected with alkali, saline and acidic soil (Anonymous 2010), there is a need for utilization of these wastelands for sericulture where normal agricultural crops cannot be raised very profitably.

Alkali soils can be defined as salt affected soils with $\mathrm{pH}$ of saturated soil paste of more than 8.5 and electrical conductivity (EC) of saturated extract of less than $4 \mathrm{mmhos} / \mathrm{cm}^{2}$ and exchangeable sodium percentage (ESP) of more than 15 (Richards, 1954). The alkalization of South Indian soils is characterized by high $\mathrm{pH}(>8.5)$, high ESP (>15), toxicity of alkali salts viz., carbonates and bicarbonates. Normally, alkali soils are low in nitrogen, medium to high in phosphorous and high in potassium contents, whereas in case of micro-nutrients, contents of $\mathrm{Zn}, \mathrm{Fe}, \mathrm{Mn}, \mathrm{Cu}$ are low and contents of Boron and Molybdenum are high compared to normal fertile soils (Bhumbla and Dhingra, 1964). These alkali soils could be effectively utilized either by reclamation or by growing alkali tolerant genotypes. Reclamation of alkali soils involves reversing of the process, which caused deterioration of these soils i.e., replacing excess exchangeable sodium with calcium supplied either through outside source or mobilising precipitated calcium carbonate present in soil. For this purpose, gypsum (direct sources), pyrites, sulphur, acid (indirect sources) and pressmud, green manure and farmyard manure (organic matters) are used (Somani and Totawat, 1993), which bring in desirable chemical and physical properties of soils for high productivity.

There is a dire need to identify genotypes which must be highly tolerant to alkalinity. Correlation of particular character with other characters contributing to leaf yield is of great importance for indirect selection of genotypes for higher leaf yield in mulberry. Path coefficient analysis helps partitioning the correlation coefficient into its direct and indirect effects which permit the breeders to rank the genetic characteristics according to their participation.

The primary object of the study was to critically assess the inter-varietal genetic variability and its exploitation for improving salt tolerance by screening them in salt affected soils, correlate leaf parameters with increased production of quality mulberry leaves by economic utilization of reclaimed problematic soils.

\section{Materials and Methods}

The study conducted at black cotton soil with a $\mathrm{pH}$ range $9.3-9.5$, EC range of $0.32-0.84$ mmhos/cm, Exchangeable Sodium Percentage 
(ESP) of 42 and Sodium Adsorption Ratio (SAR) of 30, clearly indicating that the experimental area is affected alkalinity and the portion of area is used as unreclaimed alkali soil.

Alkali soil were reclamated with inorganic amendment i.e. gypsum with purity of 70-80 $\%$, particle size of $>2 \mathrm{~mm}$ and sulphur at 8 and $1 \mathrm{MT} / \mathrm{ha}$, respectively was used and with organic amendment i.e. pressmud that contains relatively high soluble calcium from a sugar factory employing sulphitation process, was used at $50 \mathrm{MT} / \mathrm{ha}$.

Inorganic/ organic amendments were mixed up to $10 \mathrm{~cm}$ depth in experimental plots when soil moisture level was optimum. For mixing, shallow ploughing with country plough was carried followed by planking before the onset of monsoon. This was followed by ample irrigation to achieve a stand of 5-7 cm water on the soil surface for at least 15 days. In between, puddling was practiced to mix the amendments thoroughly in the soil for effective reclamation. After 15 days, excess water was drained out of the experimental plot through separate channels. Again the plots were irrigated and the water drained out so as to remove excess salts. This process was repeated for effective reclamation.

After reclamation with inorganic/ organic amendments, the surface of the soil was allowed to dry completely. Then the land was prepared with proper leveling with little or no slope along the width to facilitate movement of water along the length in a uniform sheet with desired depth of application. Chemical properties of soil samples were analyzed before reclamation and periodically after reclamation with inorganic and organic amendments along with irrigation. Soil analysis of all the treatments for its chemical properties like Soil $\mathrm{pH}$, Electrical Conductivity (EC), Exchangeable Sodium
Percentage (ESP) and Sodium Adsorption Ratio (SAR) following the method suggested by Jackson (1973).

Five mulberry genotypes (AR-12, AR-14, AR-10, AR-08 and AR-29) and two improved checks (V1, S34) and one local check were used in the experiment. The experiment was conducted in alkali affected soil at Central Sericulture Research and Training Institute, Central Silk Board, Mysuru. Sixty four plants were maintained per genotype and replication in the net plot. Each net plot/ replication was surrounded by a row of border plants. Three experiments were maintained separately and each of the experiment was conducted following Randomized Block Design with three replications. The plantation was established in the field during monsoon season by planting six month old saplings with $90 \mathrm{~cm} \times 90 \mathrm{~cm}$ spacing. All regular intercultural operations were attended as per the recommended package of practices.

After an initial period of establishment of one year, the plants were pruned at a stump height of $30 \mathrm{~cm}$ from the ground level. After pruning and digging, farmyard manure was applied at $20 \mathrm{MT} / \mathrm{ha}$. /year in two split doses and thoroughly mixed with the soil by ploughing. The fertilizer schedule followed was $300: 120: 120 \mathrm{~kg}$ of NPK/ha/year in five split doses of 60:60:60 kg NPK/ha after I and III crop and $60 \mathrm{~kg}$ nitrogen/ha after II, IV and V crops. Five leaf harvests were made in each year by leaf plucking method. The genotypes were evaluated for morphological (leaf yield/ha/year, no. of shoot per plant, total shoot length per plant, no. of nodes per meter), physiological (leaf area, specific leaf weight, leaf moisture \%), leaf yield and qualitative parameters.

Phenotypic and genotypic correlation coefficient between two characters were worked out by variance-covariance analysis 
separately for different amendment treatments as per the method followed by Al-Jibouri et al., (1958) using the formula.

Correlation Coefficient (r) $=\frac{6 x y}{\sqrt{62 x .62 y .}}$

Where, $x y$ is the covariance of the characters, $x$ and $y$, while $\sigma^{2} x$ and $\sigma^{2} y$ are the variance of characters $\mathrm{x}$ and $\mathrm{y}$, respectively. Considering phenotypic (бpi and бpipj) and genotypic values $\left(\sigma^{2}\right.$ gi and $\sigma$ gigj), phenotypic and genotypic correlation were worked out, respectively.

As the leaf yield is the end product for the evaluation study, path analysis was performed separately for different treatments regarding the yield character of the resultant and other significant parameters as casual agents. The path Co-efficient analysis was done at genotypic level following Dewey and $\mathrm{Lu}$ (1959) using characters. A Path Co-efficient is simply a standardized partial regression coefficient and is attained by the simultaneous solution of the equations, which express the basic relationship between correlations and path co-efficient. Path Co-efficient analysis is done separately for all the treatments viz., unreclaimed alkali soil, soil reclaimed with inorganic amendments and organic amendments

\section{Results and Discussion}

\section{Reclamation of soil properties}

Chemical properties of experimental plots soil viz., unreclaimed alkaline soil, soils reclaimed with inorganic (Gypsum) and organic (Pressmud) amendments were analysed, data presented in Table 1. Average $\mathrm{pH}$ of the experimental site was recorded as 9.5, whereas soils reclaimed with inorganic (Gypsum) and organic amendments (Pressmud) exhibited a $\mathrm{pH}$ of 8.3 and 7.9, respectively. Average Electric conductivity (EC) of unreclaimed alkali soils was 0.58 $\mathrm{mmhos} / \mathrm{cm}$. In case of soil reclaimed with inorganic and organic amendments, the EC was 0.63 and $0.40 \mathrm{mmhos} / \mathrm{cm}$, respectively. Exchangeable sodium percentage was low in soils reclaimed with inorganic amendments $(12 \%)$ in compare with organic amendments $(18.6 \%)$ and ESP was high in unreclaimed alkali soil (42\%). Sodium Adsorption Ratio (SAR) was minimum in soils reclaimed with inorganic amendments ( $8 \%$ ) followed by soils reclaimed with organic amendments (14\%). Maximum ESP was recorded in unreclaimed alkaline soils (30\%).

\section{Correlation studies}

The correlations for different characters viz., morphological, physiological and leaf yield were computed separately for the three reclamation treatments and presented in Table 2 to 4. Analysis of variance among all characters under alkali affected soil, soil reclaimed with inorganic and organic amendment conditions was performed and results are given.

\section{Correlation coefficients of morpho- physiological parameters in different mulberry genotypes under unreclaimed alkali soils}

Correlation studies of morpho-physiological characters and leaf yield are indicated at Table 2. At phenotypic level, number of shoots was positively and significantly correlated with total shoot length $\left(0.825^{* *}\right)$. Number of shoots was negatively correlated with leaf area $\left(-0.478^{*}\right)$, specific leaf weight $(-0.521 *)$, moisture percentage of leaf ($\left.0.454^{*}\right)$ and leaf yield $(-0.321)$, but those are not significant. At the genotypic level, more or less same results were obtained. Shoot length was found to be positively correlated with number of nodes $(0.221)$ and negatively 
correlated with leaf area $\left(-0.143^{*}\right)$, specific leaf weight $(-0.251)$, moisture percentage ($0.326)$ and leaf yield (-0.024) both at phenotypic and genotypic level. None of the correlation coefficient between shoot length and other characters was significant. Number of nodes exhibited the same type of correlations with leaf area (0.081), specific leaf weight $(0.265)$, leaf yield $(0.133)$ and negatively correlated with moisture percentage (-0.140), both at phenotypic and genotypic level. None of the correlation coefficients was significant. Leaf area exhibited significant and high correlation coefficients with specific leaf weight $\left(0.797^{* *}\right)$, moisture percentage $\left(0.632^{* *}\right)$ and leaf yield $\left(0.856^{* *}\right)$ both at phenotypic and genotypic level. In case of specific leaf weight, the character of high correlation with leaf yield both at phenotypic $\left(0.706^{* *}\right)$ and genotypic $(0.951 * *)$ level but its correlation with moisture percentage was not significant at phenotypic level (0.389) but significant at genotypic level $(0.529 * *)$. Moisture percentage of leaf was found to be positive and significantly correlated with yield at both phenotypic $(0.546 * *)$ and genotypic level $(0.559 * *)$. The estimates of genotypic correlation coefficients were similar in sign but higher in magnitude than the ones observed at phenotypic level for all characters. These traits seem to be more prone to environmental fluctuations, which may have diluted the expression of correlations between a character pair at phenotypic level.

\section{Correlation coefficients of morpho- physiological parameters in different mulberry genotypes under soil reclaimed with inorganic amendments}

The correlation of different morphophysiological parameters and leaf yield indicated in Table 3. Number of shoots was positively correlated with total shoot length $(0.868 * *)$ and number of nodes $(0.037)$ at phenotypic level. However, the correlation was significant with total shoot length and it was low with number of nodes. Number of shoots was negatively correlated with leaf area $(-0.252)$, specific leaf weight $(-0.110)$, moisture percentage of leaf $(-0.083)$ and leaf yield (-0.088), but those are not significant. At the genotypic level, more or less same results were obtained except for number of nodes (-0.077), which showed low and negative correlation with number of shoots. Shoot length was found to be positively correlated with specific leaf weight (0.043) and leaf yield (0.00) and negatively correlated with leaf area (-0.135) and moisture percentage (-0.116) and both at phenotypic and genotypic level. It had positive correlation with number of nodes at phenotypic (0.016) and negative correlation at genotypic (-0.011) level. None of the correlation coefficient between shoot length and other characters was significant. Number of nodes exhibited the same type of positive correlations with leaf area (0.220), specific leaf weight (0.033), moisture percentage $(0.140)$ and leaf yield $(0.183)$ both at phenotypic and genotypic level. None of these correlation coefficients was significant. Leaf area exhibited significant and high correlation coefficients with specific leaf weight $(0.804 * *)$, moisture percentage $(0.713 * *)$ and leaf yield $(0.859 * *)$ both at phenotypic and genotypic level. In case of specific leaf weight, the character of high correlation with moisture percentage $\left(0.533^{*}\right)$ and leaf yield $(0.837 * *)$ both at phenotypic and genotypic level. But correlation coefficients at genotypic level were highly significant than at phenotypic level. Moisture percentage of leaf was found to be positive and significantly correlated with yield at both phenotypic $(0.579 * *)$ and genotypic $(0.601 * *)$ level. Similar to unreclaimed alkali soils, the estimates of genotypic correlation coefficients were similar in sign but higher in magnitude than the ones observed at phenotypic level for 
all characters. These traits seem to be more prone to environmental fluctuations, which may have diluted the expression of correlations between a character pair at phenotypic level.

\section{Correlation coefficients of morpho- physiological parameters in different mulberry genotypes under soil reclaimed with organic amendments}

Correlation studies of morpho-physiological characters and leaf yield under soil reclaimed with organic amendments are indicated at Table 4, which are almost similar to the treatment, unreclaimed alkali soil. At phenotypic level, number of shoots was positively and significantly correlated with total shoot length $\left(0.925^{* *}\right)$. Number of shoots was negatively correlated with leaf area $(-0.278)$, specific leaf weight $(-0.165)$, moisture percentage of leaf $(-0.247)$ and leaf yield (-0.032), but those are not significant. Number of shoots had a low positive correlation with number of nodes (0.213). At the genotypic level, more or less same results were obtained, except the correlation with specific leaf weight (0.348), which was positive and significant. Shoot length was found to be positively correlated with number of nodes (0.007) and negatively correlated with leaf area (-0.211), specific leaf weight (0.076), moisture percentage (-0.274) and leaf yield (-0.014) both at phenotypic level. Though, same correlation coefficients were recorded at genotypic level except for specific leaf weight (0.407), which was positive and significant. Other correlation coefficients between shoot length and other characters were significant. Number of nodes exhibited the low, positive correlations with leaf area (0.027), specific leaf weight (0.201), moisture percentage (0.110) and leaf yield both at phenotypic (0.093) and genotypic (0.103) level. None of the correlation coefficients was significant. Leaf area exhibited significant and high correlation coefficients with specific leaf weight $\left(0.584^{* *}\right)$, moisture percentage $(0.700 * *)$ and leaf yield both at phenotypic $(0.817 * *)$ and genotypic $\left(0.873^{* *}\right)$ level. In case of specific leaf weight, the character of high correlation with leaf yield both at phenotypic $(0.578 * *)$ and genotypic $(2.584 * *)$ level but its correlation with moisture percentage (0.342) was not significant at phenotypic level but significant at genotypic $(1.974 * *)$ level. Similar correlation was recorded by moisture percentage of leaf, which was found to be positive and significant with yield at both phenotypic $\left(0.566^{* *}\right)$ and genotypic $\left(0.586^{* *}\right)$ level. The estimates of genotypic correlation coefficients were similar in sign but higher in magnitude than the ones observed at phenotypic level for all characters. These traits seem to be more prone to environmental fluctuations, which may have diluted the expression of correlations between a character pair at phenotypic level.

\section{Path analysis}

Direct and indirect effects of different morpho-physiological parameters of different mulberry genotypes under different treatments are furnished at Table 5 to 7.

\section{Path analysis of morpho-physiological parameters in different mulberry genotypes under unreclaimed alkali soils}

The path analysis with direct and indirect effects different morpho-physiological parameters and their correlation with leaf yield under unreclaimed alkali soils are indicated at Table 5 and Fig. 1. Number of shoots had a positive and strong direct effects (0.133) on leaf yield, but its effect was considerably reduced and resulted to a negative correlation with yield due to indirect effect through negative values via leaf area ($0.377)$ and specific leaf weight $(-0.062)$ and moisture percentage $(-0.026)$. 
Table.1 Correlation coefficients of morpho-physiological parameters in different mulberry genotypes under unreclaimed alkali soil

\begin{tabular}{|c|c|c|c|}
\hline \multirow[b]{2}{*}{ Parameters } & \multirow{2}{*}{$\begin{array}{l}\text { Un- } \\
\text { reclaimed } \\
\text { alkali soil }\end{array}$} & \multicolumn{2}{|c|}{ After reclamation with } \\
\hline & & $\begin{array}{c}\text { inorganic } \\
\text { amendments }^{\#}\end{array}$ & $\begin{array}{c}\text { organic } \\
\text { amendments }\end{array}$ \\
\hline $\mathrm{pH}$ & 9.50 & 7.90 & 8.30 \\
\hline Electrical Conductivity (mmhos/cm) & 0.58 & 0.63 & 0.40 \\
\hline Exchangeable Sodium Percentage & 42.00 & 12.00 & 18.60 \\
\hline Sodium Adsorption Ratio (\%) & 30.00 & 8.00 & 14.00 \\
\hline ulphur@ & & & \\
\hline
\end{tabular}

Table.2 Correlation coefficients of morpho-physiological parameters in different mulberry genotypes under unreclaimed alkali soil

\begin{tabular}{|c|c|c|c|c|c|c|c|}
\hline Parameter & $\begin{array}{l}\text { No. of } \\
\text { shoots }\end{array}$ & $\begin{array}{l}\text { Shoot } \\
\text { length }\end{array}$ & $\begin{array}{l}\text { No. of } \\
\text { nodes }\end{array}$ & $\begin{array}{l}\text { Leaf } \\
\text { area }\end{array}$ & $\begin{array}{l}\text { Specific } \\
\text { Leaf } \\
\text { Weight }\end{array}$ & $\begin{array}{l}\text { Moisture } \\
\text { percentage }\end{array}$ & Yield \\
\hline $\begin{array}{l}\text { No. of } \\
\text { shoots }\end{array}$ & & $0.825 * *$ & 0.177 & $-0.478 *$ & $-0.521 *$ & $-0.454 *$ & -0.321 \\
\hline $\begin{array}{l}\text { Shoot } \\
\text { length }\end{array}$ & $0.907 * *$ & & 0.221 & -0.143 & -0.251 & -0.326 & -0.024 \\
\hline $\begin{array}{l}\text { No. of } \\
\text { nodes }\end{array}$ & 0.225 & 0.258 & & 0.081 & 0.265 & -0.140 & 0.133 \\
\hline Leaf area & $-0.532 *$ & -0.164 & 0.050 & & $0.797 * *$ & $0.632 * *$ & $0.856 * *$ \\
\hline $\begin{array}{l}\text { Specific } \\
\text { Leaf } \\
\text { Weight }\end{array}$ & $-0.704 * *$ & -0.411 & 0.214 & $1.010 * *$ & & 0.389 & $0.706 * *$ \\
\hline $\begin{array}{l}\text { Moisture } \\
\text { percentage }\end{array}$ & $-0.461 *$ & -0.351 & -0.223 & $0.680 * *$ & $0.529 *$ & & $0.546 * *$ \\
\hline Yield & -0.341 & -0.062 & 0.128 & $0.926 * *$ & $0.951 * *$ & $0.559 * *$ & \\
\hline
\end{tabular}


Table.3 Correlation coefficients of morpho-physiological parameters in different mulberry genotypes under soil reclaimed with inorganic amendments (Gypsum @8 MT/ha. + Sulphur @ 1MT/ha.)

\begin{tabular}{|c|c|c|c|c|c|c|c|}
\hline Parameter & $\begin{array}{l}\text { No. of } \\
\text { shoots }\end{array}$ & $\begin{array}{l}\text { Shoot } \\
\text { length }\end{array}$ & $\begin{array}{l}\text { No. of } \\
\text { nodes }\end{array}$ & $\begin{array}{l}\text { Leaf } \\
\text { area }\end{array}$ & $\begin{array}{l}\text { Specific } \\
\text { Leaf } \\
\text { Weight }\end{array}$ & $\begin{array}{l}\text { Moisture } \\
\text { percentage }\end{array}$ & Yield \\
\hline No. of shoots & & $0.868 * *$ & 0.037 & -0.252 & -0.110 & -0.083 & -0.088 \\
\hline Shoot length & $1.003 * *$ & & 0.016 & -0.135 & 0.043 & -0.116 & 0.000 \\
\hline No. of nodes & -0.077 & -0.011 & & 0.220 & 0.033 & 0.140 & 0.183 \\
\hline Leaf area & -0.339 & -0.170 & 0.270 & & $0.804 * *$ & $0.713 * *$ & $0.859 * *$ \\
\hline $\begin{array}{l}\text { Specific Leaf } \\
\text { Weight }\end{array}$ & -0.126 & 0.047 & 0.062 & $1.035^{* * *}$ & & $0.533 *$ & $0.837 * *$ \\
\hline $\begin{array}{l}\text { Moisture } \\
\text { percentage }\end{array}$ & -0.110 & -0.137 & 0.127 & $0.722 * *$ & $0.659 * * *$ & & $0.579 * *$ \\
\hline Yield & -0.125 & 0.017 & 0.240 & $0.908 * *$ & $1.003 * *$ & $0.601 * *$ & \\
\hline
\end{tabular}

* Significant at 5\%

** Significant at $1 \%$

Phenotypic correlation (lower diagonal)

Genotypic correlation (upper diagonal)

Table.4 Correlation coefficients of morpho-physiological parameters in different mulberry genotypes under soil reclaimed with organic amendments (Pressmud @ 50 MT/ha.)

\begin{tabular}{|c|c|c|c|c|c|c|c|}
\hline Parameter & $\begin{array}{l}\text { No. of } \\
\text { shoots }\end{array}$ & $\begin{array}{l}\text { Shoot } \\
\text { length }\end{array}$ & $\begin{array}{l}\text { No. of } \\
\text { nodes }\end{array}$ & $\begin{array}{l}\text { Leaf } \\
\text { area }\end{array}$ & $\begin{array}{l}\text { Specific } \\
\text { Leaf } \\
\text { Weight }\end{array}$ & $\begin{array}{l}\text { Moisture } \\
\text { percentage }\end{array}$ & Yield \\
\hline $\begin{array}{l}\text { No. of } \\
\text { shoots }\end{array}$ & & $0.925 * *$ & 0.213 & -0.278 & -0.165 & -0.247 & -0.032 \\
\hline $\begin{array}{l}\text { Shoot } \\
\text { length }\end{array}$ & $0.993^{* *}$ & & 0.007 & -0.211 & -0.076 & -0.274 & -0.014 \\
\hline No. of nodes & 0.203 & 0.065 & & 0.027 & 0.20 & 0.110 & 0.093 \\
\hline Leaf area & -0.317 & -0.224 & 0.065 & & $0.584 * *$ & 0.700 ** & $0.817 * *$ \\
\hline $\begin{array}{l}\text { Specific } \\
\text { Leaf Weight }\end{array}$ & 0.348 & 0.407 & 0.138 & $2.633 * *$ & & 0.342 & $0.578^{* * *}$ \\
\hline $\begin{array}{l}\text { Moisture } \\
\text { percentage }\end{array}$ & -0.302 & -0.308 & 0.116 & $0.744 * *$ & $1.974 * *$ & & $0.566 * *$ \\
\hline Yield & -0.036 & -0.003 & 0.103 & $0.873 * *$ & $2.584 * *$ & $0.586 * *$ & \\
\hline
\end{tabular}

* Significant at 5\%

** Significant at $1 \%$

Phenotypic correlation (lower diagonal)

Genotypic correlation (upper diagonal) 
Table.5 Genotypic path coefficient analysis - Direct (diagonal underlined) and indirect effects of different morpho-physiological parameters on leaf yield under unreclaimed alkali soils

\begin{tabular}{|l|c|c|c|c|c|c|c|}
\hline Parameter & $\begin{array}{l}\text { No. of } \\
\text { shoots }\end{array}$ & $\begin{array}{l}\text { Shoot } \\
\text { length }\end{array}$ & $\begin{array}{l}\text { No. of } \\
\text { nodes }\end{array}$ & $\begin{array}{l}\text { Leaf } \\
\text { area }\end{array}$ & $\begin{array}{l}\text { Specific } \\
\text { Leaf Weight }\end{array}$ & $\begin{array}{l}\text { Moisture } \\
\text { percentage }\end{array}$ & $\begin{array}{l}\text { Correlation } \\
\text { with yield }\end{array}$ \\
\hline No. of shoots & $\underline{\mathbf{0 . 1 3 3}}$ & $\mathbf{0 . 0 1 5}$ & $\mathbf{0 . 0 0 0 6}$ & $\mathbf{- 0 . 3 7 7}$ & $\mathbf{- 0 . 0 6 2}$ & $\mathbf{- 0 . 0 2 6}$ & $\mathbf{- 0 . 3 1 7}$ \\
\hline Shoot length & $\mathbf{0 . 1 0 8}$ & $\underline{\mathbf{0 . 0 1 8}}$ & $\mathbf{0 . 0 0 0 8}$ & $\mathbf{- 0 . 1 1 3}$ & $\mathbf{- 0 . 0 2 9}$ & $\mathbf{- 0 . 0 1 8}$ & $\mathbf{- 0 . 0 3 3}$ \\
\hline No. of nodes & $\mathbf{0 . 0 2 2}$ & $\mathbf{0 . 0 0 4}$ & $\underline{\mathbf{0 . 0 0 4}}$ & $\mathbf{0 . 0 6 4}$ & $\mathbf{0 . 0 3 1}$ & $\mathbf{- 0 . 0 0 7}$ & $\mathbf{0 . 1 1 7}$ \\
\hline Leaf area & $\mathbf{- 0 . 0 6 3}$ & $\mathbf{- 0 . 0 0 3}$ & $\mathbf{0 . 0 0 0 3}$ & $\underline{\mathbf{0 . 7 9 7}}$ & $\mathbf{0 . 0 9 4}$ & $\mathbf{0 . 0 3 5}$ & $\mathbf{0 . 8 5 5} * *$ \\
\hline Specific Leaf Weight & $\mathbf{- 0 . 0 6 9}$ & $\mathbf{- 0 . 0 0 4}$ & $\mathbf{0 . 0 0 1}$ & $\mathbf{0 . 6 2 2}$ & $\underline{\mathbf{0 . 1 2 0}}$ & $\mathbf{0 . 0 2 3}$ & $\mathbf{0 . 6 9 2} * *$ \\
\hline Moisture percentage & $\mathbf{- 0 . 0 6 0}$ & $\mathbf{- 0 . 0 0 6}$ & $\mathbf{- 0 . 0 0 0 5}$ & $\mathbf{0 . 4 8 7}$ & $\mathbf{0 . 0 4 8}$ & $\underline{\mathbf{0 . 0 5 7}}$ & $\mathbf{0 . 5 2 8} *$ \\
\hline
\end{tabular}

Residual: $\mathbf{0 . 2 5 3 3}$

* Significant at $5 \%$

** Significant at $1 \%$

Table.6 Genotypic path coefficient analysis - Direct (diagonal underlined) and indirect effects of different morpho-physiological parameters on leaf yield under soil reclaimed with inorganic amendments (Gypsum @ 8 MT/ha. +Sulphur @ 1MT/ha.)

\begin{tabular}{|l|c|c|c|c|c|c|c|}
\hline Parameter & $\begin{array}{l}\text { No. of } \\
\text { shoots }\end{array}$ & $\begin{array}{l}\text { Shoot } \\
\text { length }\end{array}$ & $\begin{array}{l}\text { No. of } \\
\text { nodes }\end{array}$ & $\begin{array}{l}\text { Leaf } \\
\text { area }\end{array}$ & $\begin{array}{l}\text { Specific } \\
\text { Leaf Weight }\end{array}$ & $\begin{array}{l}\text { Moisture } \\
\text { percentage }\end{array}$ & $\begin{array}{l}\text { Correlation } \\
\text { with yield }\end{array}$ \\
\hline No. of shoots & $\underline{\mathbf{0 . 2 2 5}}$ & $\mathbf{- 0 . 1 0 6}$ & $\mathbf{0 . 0 0 0 2}$ & $\mathbf{- 0 . 1 7 7}$ & $\mathbf{- 0 . 0 3 1}$ & $\mathbf{0 . 0 0 4}$ & $\mathbf{- 0 . 0 8 5}$ \\
\hline Shoot length & $\mathbf{0 . 1 9 2}$ & $\underline{\mathbf{- 0 . 1 2 3}}$ & $\mathbf{0 . 0 0 0 1}$ & $\mathbf{- 0 . 0 8 7}$ & $\mathbf{0 . 0 0 9}$ & $\mathbf{0 . 0 0 5}$ & $\mathbf{- 0 . 0 0 3}$ \\
\hline No. of nodes & $\mathbf{0 . 0 0 9}$ & $\mathbf{- 0 . 0 0 2}$ & $\underline{\mathbf{0 . 0 0 6}}$ & $\mathbf{0 . 1 5 0}$ & $\mathbf{0 . 0 2 4}$ & $\mathbf{- 0 . 0 0 6}$ & $\mathbf{0 . 1 8 1}$ \\
\hline Leaf area & $\mathbf{- 0 . 0 5 8}$ & $\mathbf{0 . 0 1 6}$ & $\mathbf{0 . 0 0 1}$ & $\underline{\mathbf{0 . 6 8 8}}$ & $\mathbf{0 . 2 3 8}$ & $\mathbf{- 0 . 0 3 4}$ & $\mathbf{0 . 8 5 1}$ *** \\
\hline Specific Leaf Weight & $\mathbf{- 0 . 0 2 2}$ & $\mathbf{- 0 . 0 0 4}$ & $\mathbf{0 . 0 0 0 5}$ & $\mathbf{0 . 5 1 7}$ & $\underline{\mathbf{0 . 3 1 6}}$ & $\mathbf{- 0 . 0 2 1 3}$ & $\mathbf{0 . 7 8 7} * *$ \\
\hline Moisture percentage & $\mathbf{- 0 . 0 1 9}$ & $\mathbf{0 . 0 1 4}$ & $\mathbf{0 . 0 0 0 7}$ & $\mathbf{0 . 4 8 3}$ & $\mathbf{0 . 1 4 2}$ & $\underline{\mathbf{0 . 0 4 8}}$ & $\mathbf{0 . 5 7 2}$ \\
\hline
\end{tabular}

Residual: 0.2105

* Significant at $5 \%$

** Significant at $1 \%$

Table.7 Genotypic path coefficient analysis - Direct (diagonal underlined) and indirect effects of different morpho-physiological parameters on leaf yield under soils reclaimed with organic amendments (Pressmud @ 50 MT/ha.)

\begin{tabular}{|l|c|c|c|c|c|c|c|}
\hline Parameter & $\begin{array}{l}\text { No. of } \\
\text { shoots }\end{array}$ & $\begin{array}{l}\text { Shoot } \\
\text { length }\end{array}$ & $\begin{array}{l}\text { No. of } \\
\text { nodes }\end{array}$ & $\begin{array}{l}\text { Leaf } \\
\text { area }\end{array}$ & $\begin{array}{l}\text { Specific Leaf } \\
\text { Weight }\end{array}$ & $\begin{array}{l}\text { Moisture } \\
\text { percentage }\end{array}$ & $\begin{array}{l}\text { Correlation } \\
\text { with yield }\end{array}$ \\
\hline No. of shoots & $\underline{\mathbf{0 . 2 4 0}}$ & $\mathbf{- 0 . 0 3 4}$ & $\mathbf{- 0 . 0 0 9}$ & $\mathbf{- 0 . 1 9 3}$ & $\mathbf{- 0 . 0 1 6}$ & $\mathbf{- 0 . 0 1 4 3}$ & $\mathbf{- 0 . 0 2 6}$ \\
\hline Shoot length & $\mathbf{0 . 2 1 3}$ & $\underline{\mathbf{- 0 . 0 3 9}}$ & $\mathbf{0 . 0 0 0 6}$ & $\mathbf{- 0 . 1 6 2}$ & $\mathbf{- 0 . 0 1 1}$ & $\mathbf{- 0 . 0 1 5}$ & $\mathbf{- 0 . 0 1 2}$ \\
\hline No. of nodes & $\mathbf{0 . 0 5 7}$ & $\mathbf{0 . 0 0 0 6}$ & $\underline{\mathbf{- 0 . 0 3 7}}$ & $\mathbf{0 . 0 3 3}$ & $\mathbf{0 . 0 3 3}$ & $\mathbf{0 . 0 0 5}$ & $\mathbf{0 . 0 9 2}$ \\
\hline Leaf area & $\mathbf{- 0 . 0 6 2}$ & $\mathbf{0 . 0 0 8}$ & $\mathbf{- 0 . 0 0 2}$ & $\underline{\mathbf{0 . 7 4 3}}$ & $\mathbf{0 . 0 8 6}$ & $\mathbf{0 . 0 3 9}$ & $\mathbf{0 . 8 1 3} * *$ \\
\hline Specific Leaf Weight & $\mathbf{- 0 . 0 2 4}$ & $\mathbf{0 . 0 0 3}$ & $\mathbf{- 0 . 0 0 8}$ & $\mathbf{0 . 4 0 0}$ & $\underline{\mathbf{0 . 1 5 9}}$ & $\mathbf{0 . 0 1 8}$ & $\mathbf{0 . 5 4 8} * *$ \\
\hline Moisture percentage & $\mathbf{- 0 . 0 6 0}$ & $\mathbf{0 . 0 1 0}$ & $\mathbf{- 0 . 0 0 3}$ & $\mathbf{0 . 5 1 1}$ & $\mathbf{0 . 0 5 1}$ & $\underline{\mathbf{0 . 0 5 7}}$ & $\mathbf{0 . 5 6 4} * *$ \\
\hline
\end{tabular}

Residual: $\mathbf{0 . 2 8 5 9}$

* Significant at 5\%

** Significant at 1\% 
Fig.1 Genotypic path diagram of morpho-physiological characters on leaf yield under alkali soil with no reclamation

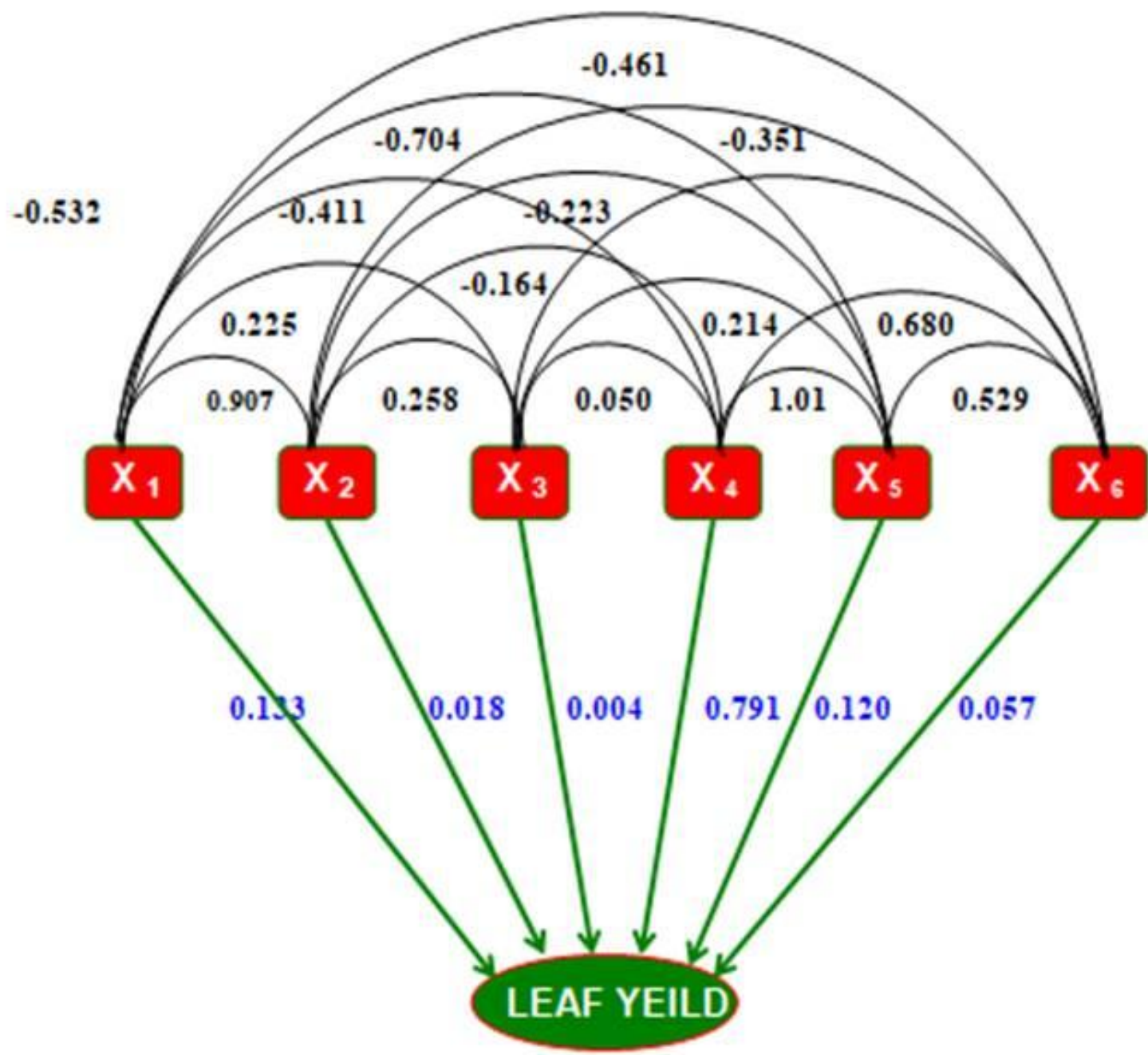

0.1777

RESIDUAL FACTOR

$\mathrm{X}_{1}$ - Number of shoots/ plant

$X_{2}$ - Shoot length/plant

$\mathrm{X}_{3}$ - Number of Nodes/meter
$\mathrm{X}_{4}$ - Leaf area/plant

$X_{5}$ - Specific Leaf Weight

$\mathrm{X}_{6}$ - Leaf Moisture Percentage

Values are direct effects of the character

Values are simple correlation coefficients (r) 
Fig.2 Genotypic path diagram of morpho-physiological characters on leaf yield under soil reclaimed with inorganic amendments

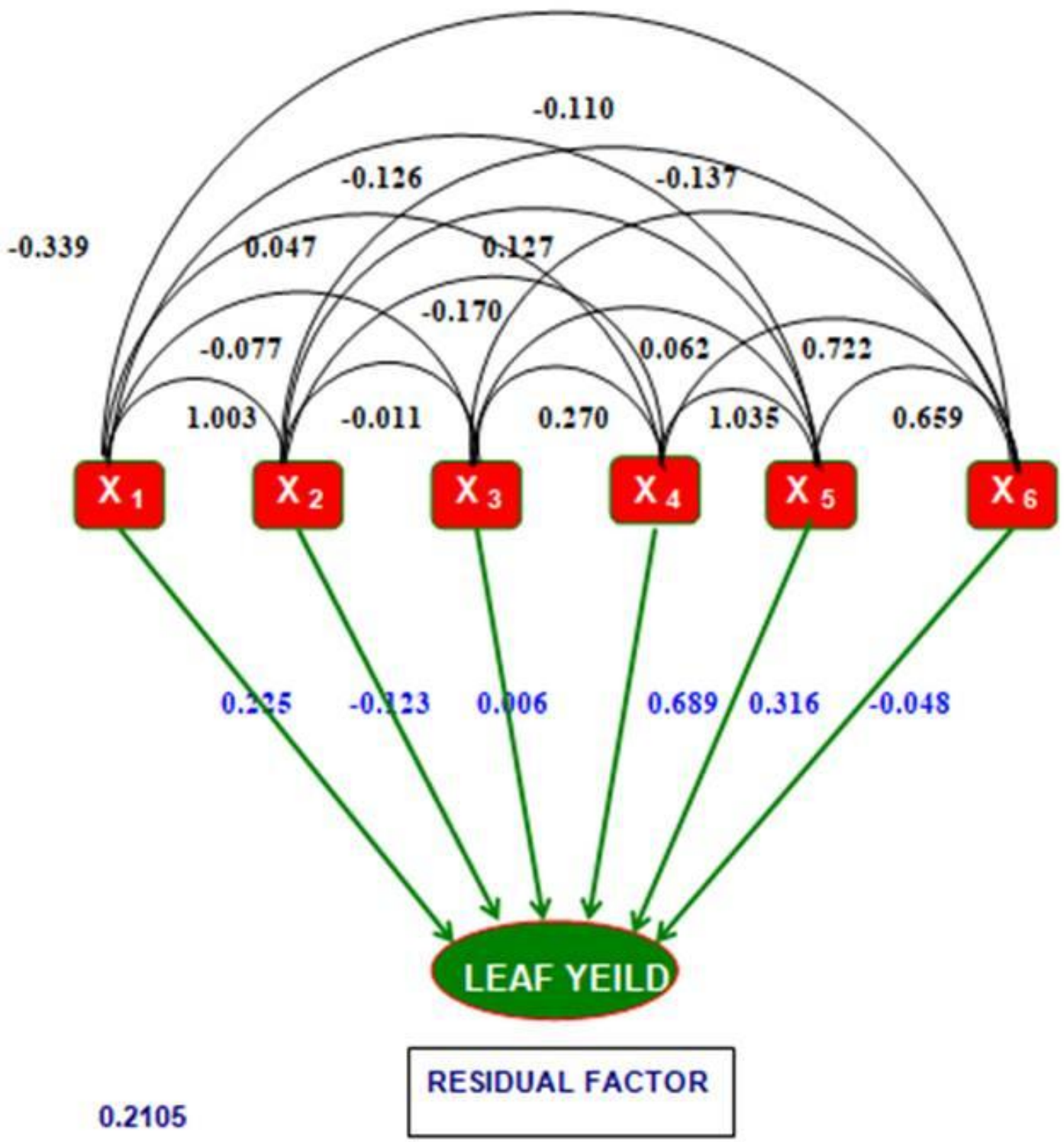

$\begin{array}{ll}X_{1}-\text { Number of shoots/ plant } & X_{4}-\text { Leaf area/plant } \\ X_{2}-\text { Shoot length/ plant } & X_{5}-\text { Specific Leaf Weight } \\ X_{3} \text { - Number of Nodes/ meter } & X_{6} \text { - Leaf Moisture Percentage }\end{array}$

Values are direct effects of the character

Values are simple correlation coefficients (r) 
Fig.3 Genotypic path diagram of morpho-physiological characters on leaf yield under soil reclaimed with organic amendments

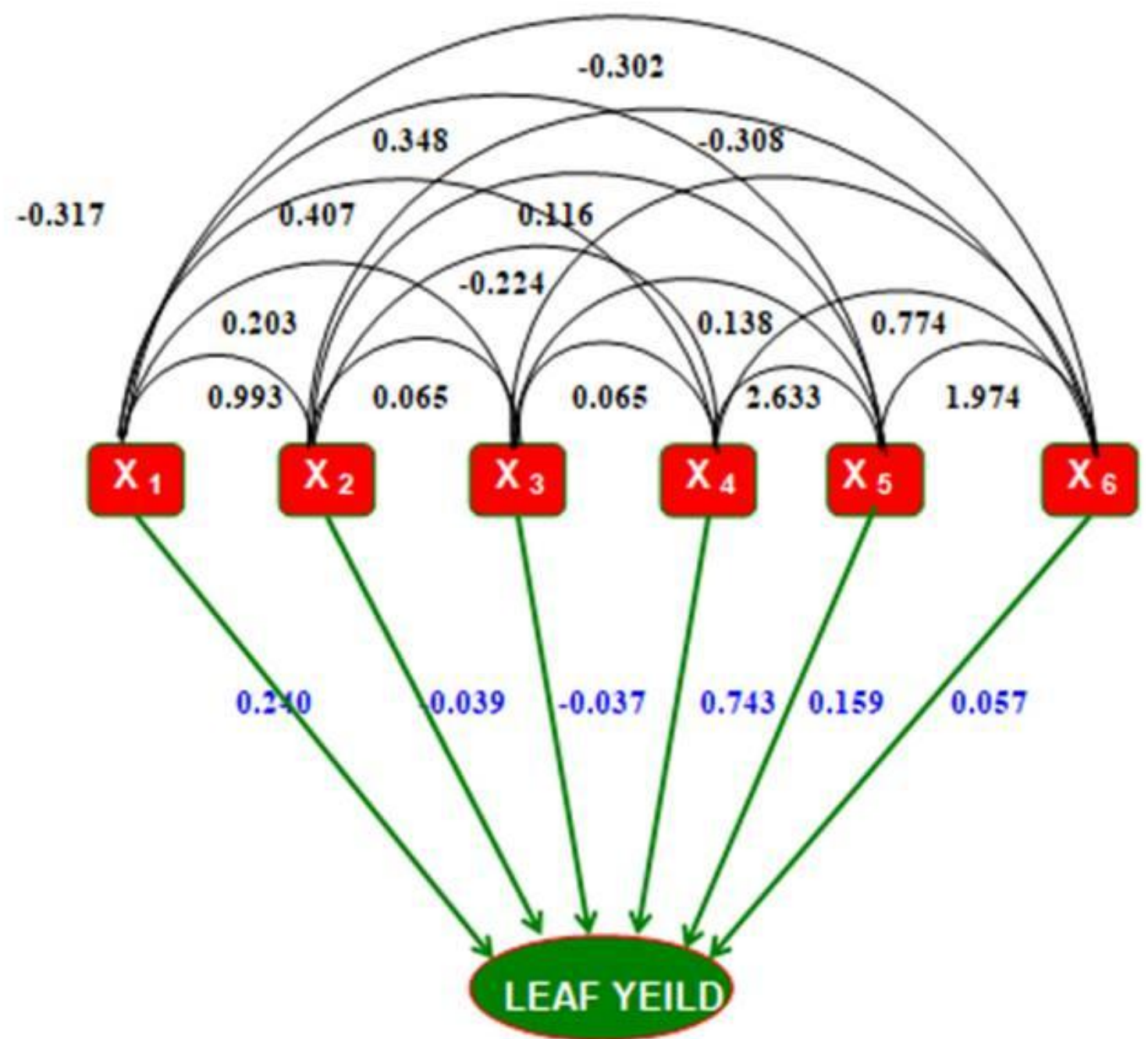

0.2859

\section{RESIDUAL FACTOR}

$\mathrm{X}_{1}$ - Number of shoots/ plant

$\mathrm{X}_{2}$ - Shoot length/ plant

$\mathrm{X}_{3}$ - Number of Nodes/ meter
$\mathrm{X}_{4}$ - Leaf area/plant

$X_{5}$ - Specific Leaf Weight

$\mathrm{X}_{6}$ - Leaf Moisture Percentage

Values are direct effects of the character

Values are simple correlation coefficients $(r)$ 
The positive strong direct effect of leaf area (0.797) and significant association with leaf yield indicated the importance of the character. Path analysis revealed the low direct effect of moisture percentage $(0.057)$ on leaf yield. In other two characters the direct effects are low but positive. The most probable reason for low direct effect of moisture percentage appears to be the outcome of its negative indirect influence via number of shoots $(-0.060)$, shoot length ($0.006)$, number of nodes $(-0.0005)$.

\section{Path analysis of morpho-physiological parameters in different mulberry genotypes under soil reclaimed with inorganic amendments}

The path analysis with direct and indirect effects different morpho-physiological parameters and their correlation with leaf yield under soil reclaimed with inorganic amendments are indicated at Table 6 and Fig. 2. Number of shoots had a low (0.225) and shoot length had a negative (-0.123) direct effect on leaf yield. Like unreclaimed alkali soil, strong direct effect of leaf area (0.688) and specific leaf weight (0.316) was observed. The association of these characters with yield was also found to be positive and significant indicated the importance of these characters. But the path analysis revealed the low direct effect of no. of nodes (0.006) on leaf yield. In case of leaf area the direct effect was quite sizeable, whereas it was negative in case of moisture percentage (-0.048).

\section{Path analysis of morpho-physiological parameters in different mulberry genotypes under soil reclaimed with organic amendments}

Number of shoots had a positive indirect effect on the leaf yield, however, its direct effect was negative on the leaf yield, due to negative values of all other parameters are indicated at Table 7 and Fig. 3. Though, shoot length (-0.039) and number of nodes (-0.037) have a low and negative direct and indirect effect on leaf yield, which may be through negative and indirect effect of leaf area ($0.162)$, specific leaf weight $(-0.011)$ and moisture percentage (-0.015). Direct effect of leaf area (0.743) and specific leaf weight (0.159) had strong positive and significant association with leaf yield indicating their importance. But the path analysis revealed the low direct effect of moisture percentage (0.057) on leaf yield, though it had a positive and highly significant correlation with the leaf yield due to positive and significant indirect effect of leaf area.

\section{Reclamation of soil properties}

In the present study, soil properties were improved with decrease in soil $\mathrm{pH}, \mathrm{EC}, \mathrm{ESP}$, SAR in both the treatments reclaimed with inorganic and organic amendments. This observation is in accordance to the findings of Subbaswamy et al., (1990), Bose et al., (1992), Bose and Majumder (1995) and Tejada et al., (2006). Dhar (1939) reported the role of molasses and pressmud in the reclamation of Usar (alkali) land. Kanwar (1962) in his reclamation study of salinealkali soil showed that both pressmud and gypsum are effective in reclamation, but pressmud was more economical.

A correlative relationship between soil $\mathrm{pH}$ and the exchangeable sodium percentage for some sodic soils has been pointed out earlier. It means ESP values have a similar change trend to soil $\mathrm{pH}$. The decrease in $\mathrm{pH}$ and ESP during reclamation of alkaline soils can be explained due to the replacement of exchangeable $\mathrm{Na}+$ ions with $\mathrm{Ca} 2+$, which is an important mechanism in decreasing $\mathrm{pH}$ during reclamation of alkaline soils (Gaind and Gaur 2003). 


\section{Correlation studies}

It has been generally accepted that correlation between different characters represents a coordination of physiological processes, which is often achieved through gene linkages (Mather and Jinks, 1971). Knowledge of the strength and type of association is an important pre-requisite for the formulation of breeding strategy. Leaf yield is a complex trait influenced by a more number of other component traits. A knowledge of the association between yield and its component traits and also between the component traits helps in improving the efficiency of selection.

In the present study the estimates of genotypic correlation coefficients were similar in sign but higher in magnitude than the ones observed at phenotypic level for all characters. These traits seem to be more prone to environmental fluctuations, which may have diluted the expression of correlations between a character pair at phenotypic level. Above observations get support from the findings of several workers viz., Mishra et al., (2001) in wheat, Srivastava et al., (2001) in Soybean, Mohanty (2001) in Brinjal and kharif onion, Neema and Palanisamy, (2001) and Jogdhande et al., (2017) in Cowpea, Khan and Sukumar, (2001) in napier grass (Pennsisetum purpureum K. Schum.) and Iyanar et al., (2001) in sorghum. They observed higher genetic correlation coefficients among different characters than the phenotypic correlation coefficients, while studying the relationship between various traits to yield. They opined that this might be due to the masking or modifying effect of the environment in genetic association between characters. They also observed shift in the correlation coefficients of yield components with yield as well as component characters and attributed it to the differences in the gene complementation of the linkage blocks. It appears interesting that increase of leaf area with succulent leaves contributes more towards yield increase in mulberry as was reported in rice (Abarshahr et al., 2011, Padmavathi et al., 1996, Panja et al., 2017). These characters are always considered to be the vital ones. The increase of leaf area ensures higher photosynthesis and high moisture content always related with the high acceptability of the silkworm.

\section{Path analysis}

Complete information about the complex trait like yield that is controlled by several other traits either directly or indirectly cannot be given by correlation co-efficient alone. Hence, the path coefficient analysis would be quite useful as it permits the separation of direct effect from indirect relation through other related traits by partitioning genotypic correlation coefficients (Dewey and Lu., 1959). Studies related to path coefficient analysis and direct and indirect effect of different traits on leaf yield under salt stress and reclaimed soil conditions are not available in mulberry. However, path coefficient studies revealed that only leaf area registered strong positive direct effect on leaf yield, under all the conditions viz., alkali soil without reclamation, soil reclaimed with inorganic amendments and organic amendments. It may also be noticed that maximum indirect effects on leaf yield were exerted by leaf area through specific leaf weight and leaf moisture. Thus from the study it is apparent that improvement in leaf area is the most important while developing a high yielding genotype tolerant to alkali soil (Abarshahr et al., 2011, Bhutta et al., 2019). In absence of studies on path analysis under salt stress conditions in mulberry, it may be concluded that the leaf area has its maximum control on leaf yield through its direct effect as well as its indirect effect via other traits especially specific leaf weight and leaf moisture percentage. This may be attributed 
to reduction in salt concentration at root zone due to lower rates of evaporation from the soil surface. The highest leaf area has been recorded in the genotype AR-12 that has contributed towards higher yield. The reason for higher leaf area contributing to higher yield also might be due to the shading effect caused by the leaves, which prevents mobilization of salts on the upper surface of soil.

In conclusion, the estimates of genotypic correlation coefficients were similar in sign but higher in magnitude than the ones observed at phenotypic level for all characters. These traits seem to be more prone to environmental fluctuations, which may have diluted the expression of correlations between a character pair at phenotypic level. These studies give the breeder the freedom to choose any environment for breeding studies in mulberry for alkali tolerance.

Under all the environments employed in the present study, leaf area, specific leaf weight and leaf moisture percentage exhibited positive and significant correlation at both phenotypic as well as genotypic level with leaf yield. This change in the trend of character association of morpho-physiological traits with leaf yield might be attributed to genotypic variation of mulberry under the alkali stress and higher contribution of leaf area and specific leaf weight to leaf yield. Leaf area registered strong positive direct and also indirect effect on leaf yield through other characters, under all the environments. Hence, leaf area could be considered as suitable criteria while developing superior genotypes tolerant to alkali soil.

\section{Acknowledgments}

I wish to thank Dr. T. Mogili and Dr. A. Sarkar for their valuable technical support and guidance on this study besides Central Silk Board, Bengaluru for the financial support.

\section{References}

Abarshahr, M., Rabiei B. and Lahigi, H.S. 2011. Genetic variability, correlation and path analysis in rice under optimum and stress irrigation regimes. Not. Sci. Biol., 3: 134-142.

Al-Jibouri, H.A., Miller, P.A. and Robinson, H.P. 1958. Genotypic and environmental variances in upland cotton of inter specific origin. Agron. J. 50: 633-637.

Anonymous. 1975. Text book of Tropical Sericulture. Japan Overseas Co-operation Volunteers, Tokyo, Japan, pp. 118-193.

Anonymous. 2010. Degraded and Wastelands of India-Status and Spatial Distribution published by ICAR, New Delhi, India

Anonymous. 2019. Mulberry and Vanya raw silk production statistics, Central Silk Board, Bengaluru, India

Bhumbla, D. R. and Dhingra, D. R. 1964. Micronutrient status for saline and alkali soils of the Punjab, J. Indian Soc. Soil Sci., 12: 255-260.

Bhutta, M. A., Munir, S., Qureshi, M. K., Shahzad, A. N., Aslam, K., Manzoor, H. and Shabir, G. 2019. Correlation and path analysis of morphological parameters contributing to yield in rice (Oryza sativa) under drought stress. Pak. J. Bot., 51(1): 73-80, 2019.

Bose, P. C. and Majumder, S.K. 1995. studies on the effect of soil amendments on productivity of mulberry in sodic soils and its economics. Ind. J. Seric. 34(1):7678.

Bose, P. C., Majumder, S. K. and Datta, R. K. 1992. Effect of amendments on chemical properties of alkali soils of mulberry garden and its yield. Ind. J. Seric. 31(2): 147-150.

Dewey, D. R. and Lu, K.H. 1959. A correlation and path coefficient analysis of component of crested wheat grass seed production. Agron. J., 51: 515-518.

Dhar, N. R. 1939. Molasses and pressmud in Usar (alkali) land reclamation. J. Ind. Chem. Soc. 2: 105-111.

Gaind, S. and Gaur, A. C. 2003. Quality 
assessment of compost prepared from fly ash and crop residue, Bioresource Technology, 87 (1): 125-127.

Iyanar, K., Gopalan, A. and Ramasamy, P. 2001. Correlation and path analysis in sorghum. Ann. Agric. Res., 22 (4): 495497.

Jackson, M. L. 1973. Soil Chemical Analysis, Prentice Hall of India Private Limited, 1st edition, New Delhi, India.

Jogdhande, S., Kale, V. S. and Nagre, P.K. 2017. Correlation and Path Analysis Study in Cowpea (Vigna unguiculata L. Walp.) Genotypes. Int. J. Curr. Microbiol. App. Sci. 6(6): 3305-3313.

Kanwar, J. S. 1962. Reclamation of saline-alkali soils- Amendments, kinds, amounts and costs. Proc. Sem. Salinity and Alkali soils. Probl. New Delhi, Pp. 61-67.

Khan, A. K. F. and Sukumar, K. 2001. Genotypic and phenotypic correlation and path analysis in napier grass. Madras Agric. J. 89(1-3): 164-166.

Mather, K. and Jinks, J.L. 1971. Biometrical Genetics. Second edition. Champman and Hall Ltd., London.

Mishra, A. N., Kaushal, K. and Pandey, H. N. 2001. Appropriate pathotypes of stem rust and leaf rust for evaluating resistance in durum wheat and bread wheat. Wheat information service. $93: 38-39$.

Mohanty, B. K. 2001. Genetic variability, correlation and path coefficient studies in Brinjal. Ann. Agric. Res., 22 (1): 59-63.

Neema, V. P. and Palaniswamy, G. A., 2001. Path analysis of $F_{2}$ generation in Cowpea. Annals of Agricultural Research, 22: 535538.

Padmavathi, N., Mahadevappa, M. and Reddy, O. U. K. 1996. Association of various yield components in rice (Oryza sativa
L.). Crop Res. Hisar., 12: 353-357.

Panja, S., Garg, H. S., Debnath, K., Sarkar, K. K., Mukherjee, S. and Bhattacharya, C. 2017. Effect of water stress on different morphological traits of rice (Oryza sativa L.) genotypes in red and laterite zone of West Bengal. Internal Journal of Advanced Biotechnology Research, 7: 419-425.

Rangaswami, G., Narasimhanna, M. M., Sastry, C. R. and Jolly, M. S. 1976. Mulberry cultivation. Sericulture manual. FAO, Rome,

Richards, L. A. 1954. Diagnosis and improvement of saline and alkali soils, Agric. Handbook, 60 USDA, Washington D.C. Pp. 104-105.

Somani, L. L. and Totawat, K. L. 1993. Use of amendments for reclamations of alkali soils (Eds.) In: Management of Saltaffected soils and waters, Agrotech Publishing Academy, Udaipur, Pp. 38.

Srivastava, A., Gupta, V., Pental, D., Pradhan, A. K. 2001. AFLP based genetic diversity assessment amongst agronomically important natural and some newly synthesized lines of Brassica juncea. Theor Appl Genet. 102: 193-199.

Subbaswamy, M. R., Munirathnam, Reddy. M., Mallikarjuna, B. and Sengupta, K. 1990. Effect of amendments on soil properties and mulberry crop yield in an alkali soil. Indian J. Seric. 29 (2): 279-281.

Tejada, M., Garcia, C., Gonzalez, J. and Hernandez, M. 2006. Use of organic amendment as a strategy for saline soil remediation: influence on the physical, chemical and biological properties of soil. Soil Biol Biochem 38: 1413-1421.

Venkatanarasaiah P. 1992. Sericulture in India, Ashish Publishing House, New Delhi.

\section{How to cite this article:}

Sathyanarayana, K. and Sangannavar, P. A. 2020. Correlation and Path Analysis of Morphophysiological Parameters Contributing to Leaf Yield in Mulberry (Morus alba L.,) under Salt Affected Soils in India. Int.J.Curr.Microbiol.App.Sci. 9(05): 2118-2133.

doi: https://doi.org/10.20546/ijcmas.2020.905.242 